\section{Aleksandra Bartosiewicz}

(iD) https://orcid.org/0000-0002-6464-9277

Department of Operational Research Faculty of Economics and Sociology University of Lodz, Łódź, Poland aleksandra.bartosiewicz@uni.lodz.pl

\section{Agnieszka Orankiewicz}

https://orcid.org/0000-0001-8718-935X

Department of City and Regional

Management

Faculty of Management

University of Lodz, Łódź, Poland

agnieszka.orankiewicz@uni.lodz.pl

\title{
The market of major film distributors in Poland in 2002-2018
}

Accepted by Editor Ewa Ziemba | Received: May 9, 2019 | Revised: October 25, 2019; November 12, 2019; November 21, 2019 | Accepted: November 27, 2019.

\begin{abstract}
Aim/purpose - The purpose of the paper is to describe and analyse the functioning of the cinema distribution market in Poland in 2002-2018.

Design/methodology/approach - The results of the quantitative research of the fifteen major film distributors operating in Poland in the analysed period are presented in the paper, together with market capacity, market share ratios and measures of market concentration.

Findings - Thanks to the analysis, large distributors operating in the Polish film market are characterised. The analysis of the structure and the concentration of the sector in question shows that nowadays over half of the cinema distribution in Poland is concentrated in the hands of four companies (UIP, Kino Świat, Monolith and Disney), two of which (UIP, Disney) are foreign branches of the major American studios. Thus, the results of the research provide empirical evidence on the impact of international distribution consortia on the Polish cinematographic industry. They are similar to the existing literature findings which concern other countries (e.g. Canada, New Zealand, Western Europe). This means that Poland is part of the trend of dominance of American distributors on global domestic markets.

Research implications/limitations - The paper opens a wider discussion about the Polish film distribution. Yet, the research results concern Poland and cannot be generalised to other countries. In addition, studies refer only to the cinema distribution, not taking into account other channels of distribution as DVD, VOD and online distribution.

Originality/value/contribution - The cinema distribution market in Poland is still poorly recognised by researchers. The paper is a valuable addition to this research gap.
\end{abstract}

Cite as: Bartosiewicz, A., \& Orankiewicz, A. (2020). The market of major film distributors in Poland in 2002-2018. Journal of Economics \& Management, 39(1), 5-20. https://doi.org/10.22367/ jem.2020.39.01 
Keywords: distribution, film, cinema, market analysis, Poland.

JEL Classification: C10, L22, Z11.

\section{Introduction}

When analysing the film market, it should be understood that the creation of a film does not end with a master copy which, in fact, finalises work on the set and in the post-production. The film distribution that follows the production is no less important for the final effect of the work, as well as for the development of the entire film industry. Distribution is an intermediate stage in the value chain $^{1}$ that links the so-called proper production with the viewer. Certainly, it is also a creative process that influences, to a large extent, future frequency and financial success of a film. Distribution may also be defined as all decisions and activities that make cinematographic products available for the public viewing in places with appropriate infrastructure (Jaciow et al., 2011; Majewska, 2017), as well as copying and secondary distribution of films (video, DVD, TV, Internet etc.). The Polish Act on cinematography which is the framework of the Polish film industry, in turn, defines the film distribution very narrowly, as "the acquisition of the right to exploit the film, including the right to make copies of the film and to adapt the film to a language version other than the one in which it was created, as well as the transfer of this right to other entities for the purpose of distributing the film" (Act on cinematography of 30 June 2005, p. 3). It seems that this definition does not take into account the challenges and tasks that distribution has to stand up to, though. We should not look at distribution as at an intermediary instrument only because it is still a sphere that clearly affects other parts of the system and thus co-shapes their nature. Distributors closely cooperate with producers - and the realities of distribution affect the producer's strategies so dependent on auditoriums, and thus also on the recognition of the audience and its preferences (Adamczak \& Klejsa, 2015).

Not only does a success or a failure of a film distribution depend on a film itself, but also on many other factors, such as a promotion, an adopted marketing strategy or an appropriate date of a premiere. The definition of a 'good film' for a cinema distributor is, however, slightly different than for a film expert or a critic. A production has the biggest potential when it attracts spectators to a cinema, thus reimbursing costs of a investment and achieving a frequency and

1 Film value chain or, more broadly - cinematographic industry value chain, consists of a number of firms and persons that work on different elements of the film production and distribution (Kehoe \& Mateer, 2015). 
cash success. At the same time, it is very difficult to predict a final financial result of a given project. For a distributor a decision to involve funds and time in a specific product is a risk that can be managed, though.

If one assumes that a distribution consists of releasing and maintaining films on the market, it may be stated that after the production, a film is simply transmitted to cinemas which are the first distribution channel responsible for its screening to the public. In reality, however, distributors are responsible for an entire screening strategy, including a choice of the number and location of cinemas in which a film should be shown. They also choose the date of a film's release, looking for periods of high demand and avoiding the dates of other films' premiers (de Vany, 2004). Distribution is, therefore, responsible for a demand on the film market, it affects a demand for various film genres, and ultimately affects a financial result of a film. Thus, distribution strategies set trends for the entire film industry, while film distributors help an audience meet a producers' work and encourage it to pay for watching films.

Another reason to study film distribution is its financial significance for the entire industry. Lobato (2007) indicates that distribution is the most profitable segment of the film industry. In addition, he emphasises that distribution is characterised by a high concentration of ownership and vertical integration.

As it turns out, however, this extremely important sector of the Polish film industry is still poorly recognised by researchers of the subject. With the exception of one monograph (Adamczak \& Klejsa, 2015) and one paper (Adamczak, 2019), there are no complete studies describing the situation of the Polish cinema distribution market. The purpose of this paper is, therefore, to analyse and describe the sector in question. The proposed text is also expected to contribute to the discussion on the film distribution in Poland. At the same time, it provides empirical evidence on the impact of large international distribution companies on the local film industry, as there are two final aims of the research:

1. The analysis of the capacity and the structure of cinema distribution market in Poland.

2. The identification of the degree of concentration on Polish film distribution market.

The rest of the paper consists of the following paragraphs: literature review (section 2), research methodology (section 3), research findings (section 4), discussion (section 5) and conclusions (section 6). 


\section{Literature review}

Many authors point to the dominance of the American film industry in the global film market (e.g. Crane, 2014; Scott, 2002; de Vany, 2004). The international success of Hollywood, especially on the feature film market, depends on the distribution activity of major studios. The situation on the Hollywood market was thoroughly described by de Vany (2004) or Scott (2004). A strong marketing campaign and extensive distribution are crucial not only for the dominance of major US companies on the domestic market, but also for an influence on foreign markets. Although films are first shown to domestic consumers in the U.S., domestic consumption is the remainder of global demand and not the only driving force of American film production (Walls \& McKenzie, 2012). Major US production companies undertake international cooperation to control distribution systems directly in all major foreign markets. United International Pictures, which is a joint venture of Universal and Paramount, controls distribution units in as many as 37 different countries on almost all continents. Its branches are located in Europe (including Great Britain, France, Germany, the Netherlands), Australia, Asia (i.e. Japan, Thailand, the Philippines), and South America (Chile, Peru). Equally, $20^{\text {th }}$ Century Fox has 21 foreign distribution branches in different countries. Moreover, if there is a country where a parent company does not actually have a distribution network, contracts or long-term agreements with local companies for a distribution of its films are usually concluded (Scott, 2004). Thus, such an influence of American consortia must have a significant impact on the development of a domestic cinematography of other countries. Crane (2014) has proved that American films and American co-productions dominate the list of top 10 films on the global and many national markets, despite protectionist cultural policies and national subsidies in many countries.

There are different studies on the impact of American giants on the development of film industries in various countries. Magder (1996) and Tepperman (2017) have proved that Canadian films suffer from the overwhelming popularity of Hollywood productions. Hollywood is a threat to the domestic film industry which faces the challenge of a fierce competition for a part of the box office. Yet, major Hollywood studios control extensive distribution and marketing networks not only in North America. Research conducted in New Zealand by Muñoz Larroa \& Ferrer-Roca (2017) showed that due to the domination of American giants, many local producers, who were looking for a market partner to distribute, promote and finance new films, had difficulty in finding an appropriate entity or did not find any at all. However, those producers who managed to sign a distribution agreement, usually perceived it as very unfavourable to them. 
The distribution in Great Britain was analysed, in turn, by Branston \& Stafford (2010) or Kehoe \& Mateer (2015). The researchers found out that tax relieves played an important role in stimulating UK economic growth by encouraging major Hollywood studios to invest in British productions. At the same time, it turns out that American majors also dominated the lucrative distribution sector, though (Kehoe \& Mateer, 2015). Moreover, according to the British Film Council, an insufficient number of British companies integrated in terms of development, production and distribution are the greatest weaknesses of the film industry in the UK. It also observes that British films should definitely be prioritised by the distribution sector (UK Film Council, 2000).

Research on market concentration in cinema distribution in Europe was also conducted. Pardo \& Sánchez-Tabarnero (2012) analysed the situation in the five largest European countries. Study was based on index $\mathrm{C} 4$ results and it has shown that the degree of market concentration in the countries studied is high: France and Italy (45\% and 55\%), Germany, the United Kingdom of Great Britain and Ireland (65\% and 67\%, respectively).

Zajiček $(1983,1992,2009)$ was the forerunner of the research on the film production in Poland and the first person who paid attention to the economic aspect of the film. The research on the film distribution in the perspective of the production culture is also continued by Adamczak and a film expert, Klejsa (Adamczak \& Klejsa, 2015). In the proposed study, in turn, the authors want to look at a film distribution in a slightly different way, through the prism of a quantitative research. Taking into account all the research described above, it turns out that the very paper provides further empirical evidence on the impact of the international distribution on the local film industries.

\section{Research methodology}

Information on 131 cinema distributors who were active in the Polish market in 2002-2018 was collected in the study. The time frame of the research depended on the availability of data in the boxoffice.pl database (Dystrybutorzy, 2018). No official statistics related to a film distribution were carried out in Poland before 2002, while 2018 was the last full year that data were possible to obtain for. Due to the partial lack of quantitative data, in the further part of the study the income, the number of viewers, the average price of tickets and the number of released films were analysed for 115 distributors that were divided into two groups. The first, which is of interest to us in the very paper, consists of 
those fifteen distributors whose individual total income in the analysed period of 2002-2018 exceeded PLN 100 million. The strategic groups were then presented with the data aggregated for every 5-6 years, that is for 2002-2007, 2008-2013 and 2014-2018, as to find out to what extent the presented analysis reflects the real characteristics of the market.

A number of statistical methods were used in the study to describe the market structure, as well as the concentration of the Polish film distribution sector together with its capacity in the near future (Mruk, 2003).

Volume (number of viewers) and value (income) market shares for individual distributors were calculated. In the paper, both absolute (formulas 1a and 1b), and relative (formula 2) market shares were used:

$$
=\frac{\begin{array}{c}
\text { Absolute value market share } \\
\text { Income of films ditributed by distributor X }
\end{array}}{\text { Income of films distributed by all distributors of the Polish market }}
$$

Absolute volume market share No of viewers of films ditributed by distributor $\mathrm{X}$

$=\overline{\text { No of viewers of films distributed by all distributors of the Polish market }}$

$$
\text { Relative market share }=\frac{\text { Market share of distributor } \mathrm{X}}{\text { Market share of the biggest competitor }}
$$

Market shares of individual distributors were then used to determine $\mathrm{C} 4$ and Herfindahl-Hirschman (HHI) indexes both in terms of value (income), and volume (number of viewers) ${ }^{2}$. The $\mathrm{C} 4$ concentration ratio means the market share of the four largest firms and it ranges from 0 to 100 . If $\mathrm{C} 4$ is close to 0 , the four largest firms in the industry would not have any significant market share, while 100 means total concentration. Herfindahl-Hirschman index, in turn, ranges from 0 to 10,000 and indicates a highly competitive industry (value close to 0 ) or high concentration (value close to 10,000 ):

where:

$$
H H I=10000 \cdot \sum_{i=1}^{n} S_{i}^{2}
$$

$S_{i}$ - absolute market share of $i$-th distributor.

2 De Vany (2004) argues that such concentration indexes as Cn and HHI should not be used in the market analysis of the film distribution industry which is unpredictable and susceptible to random fluctuations. Yet, Author's studies concentrate on American market which is much more unstable than the Polish film distribution sector. Thus, the authors of the paper calculated both measures and included them in the described study. 


\section{Research findings}

Over 3,500 films were distributed in cinemas in Poland between 2002 and 2018. They were watched by more than 569 million viewers and earned approx. PLN 10.4 billion. Major distributors (i.e. 13\% of all cinema distributors in Poland) were responsible for over 2,500 films, that is more than $70 \%$ of all films broadcast in Polish cinemas in 2002-2018. These were mainly blockbusters with absolute volume and value market shares exceeding 95\%. During the period analysed, the Polish cinema distribution market grew steadily, but it was quite unstable in terms of participating players. Many new players replaced the old ones, over half of the distributors operated on the market only for a year, and another eleven for two years. At the same time, as few as six companies (Best Film, Gutek Film, Kino Świat, Monolith, UIP, Warner) were involved in the cinema distribution throughout the entire period in question. Importantly, as many as five of fifteen major distributors of our interest were not operating in the Polish market in one or two of the analysed time windows. Next Film and Disney were absent from the market in the years 2002-2007, while it was the only period when CinePix distributed films in Poland. At the same time, two other operators, SPI (SPInka) and Vision, did not distribute any production at all for last five years (2014-2018).

\subsection{Market capacity and structure}

According to the data from Bank Danych Lokalnych (Statistics Poland, 2019a), in 2018 the number of viewers reached the 59,177,816 persons, and in the same year, the average price of cinema ticket was - PLN 19.80. It gives the approx. total value of the cinema market of PLN 1,171,720,757. Assuming that an average sum spent by Polish citizens on tickets to cinemas, theatres and concerts in 2018 amounts to less than $35 \mathrm{PLN} /$ person, it suggests that cinema holds a high first position in the structure of the household expenditure on culture (Statistics Poland, 2019b).

Between 2002 and 2013, United International Pictures (UIP) was the leader in the cinema distribution market in Poland both in terms of the size of the audience, and the amount of income received (Tables 1-2). Between 2002 and 2007, Warner, Forum Film and Monolith were its main market competitors, while in 2008-2013 Warner lost its second position in favour of Forum Film, and Kino Swiat placed itself just before the fourth Monolith. Interestingly, CinePix, who held high fifth position in the ranking of 2002-2007, was no more present on the Polish cinema market between the years 2008 and 2018. 
Table 1. Fifteen major cinema distributors in Poland by income (PLN) (2002-2007)

\begin{tabular}{|c|c|c|c|c|c|}
\hline Distributor & Income & Viewers & $\begin{array}{l}\text { No of } \\
\text { films }\end{array}$ & $\begin{array}{c}\text { Absolute } \\
\text { value share }\end{array}$ & $\begin{array}{c}\text { Absolute } \\
\text { volume } \\
\text { share }\end{array}$ \\
\hline UIP & $509,949,731$ & $32,785,567$ & 164 & 24.41 & 23.24 \\
\hline Warner & $396,339,628$ & $27,013,684$ & 108 & 18.97 & 19.14 \\
\hline Forum Film & $278,849,737$ & $19,140,259$ & 65 & 13.35 & 13.56 \\
\hline Monolith & $182,878,116$ & $12,652,633$ & 101 & 8.75 & 8.97 \\
\hline CinePix & $135,048,916$ & $9,161,618$ & 46 & 6.46 & 6.49 \\
\hline ITI Cinema (Vue Movie) & $133,306,448$ & $9,316,667$ & 34 & 6.38 & 6.60 \\
\hline SPI (SPInka) & $130,426,001$ & $8,716,031$ & 98 & 6.24 & 6.18 \\
\hline Vision & $80,198,932$ & $5,856,393$ & 53 & 3.84 & 4.15 \\
\hline Interfilm & $66,626,129$ & $5,107,896$ & 6 & 3.19 & 3.62 \\
\hline Kino Świat & $64,651,568$ & $4,247,196$ & 56 & 3.09 & 3.01 \\
\hline Best Film & $51,391,439$ & $3,420,312$ & 66 & 2.46 & 2.42 \\
\hline Gutek Film & $38,738,952$ & $2,393,200$ & 47 & 1.85 & 1.70 \\
\hline Imperial CinePix* & $20,624,967$ & $1,290,911$ & 13 & 0.99 & 0.91 \\
\hline Next Film & 0 & 0 & 0 & 0.00 & 0.00 \\
\hline Disney & 0 & 0 & 0 & 0.00 & 0.00 \\
\hline
\end{tabular}

* Imperial CinePix was created on February 2, 2007, after the merger of Imperial Entertainment and CinePix.

Table 2. Fifteen major cinema distributors in Poland by income (PLN) (2008-2013)

\begin{tabular}{|c|c|c|c|c|c|}
\hline Distributor & Income & Viewers & $\begin{array}{l}\text { No of } \\
\text { films }\end{array}$ & $\begin{array}{c}\text { Absolute } \\
\text { value share }\end{array}$ & $\begin{array}{c}\text { Absolute } \\
\text { volume } \\
\text { share }\end{array}$ \\
\hline UIP & $843,153,443$ & $42,901,804$ & 203 & 23.24 & 22.83 \\
\hline Forum Film & $531,332,720$ & $26,700,987$ & 88 & 14.65 & 14.21 \\
\hline Kino Świat & $506,349,561$ & $27,930,885$ & 145 & 13.96 & 14.86 \\
\hline Monolith & $417,536,512$ & $21,569,483$ & 149 & 11.51 & 11.48 \\
\hline Imperial CinePix & $371,089,264$ & $18,057,263$ & 81 & 10.23 & 9.61 \\
\hline Warner & $364,508,212$ & $19,119,713$ & 73 & 10.05 & 10.17 \\
\hline ITI Cinema (Vue Movie) & $294,413,304$ & $15,541,273$ & 57 & 8.12 & 8.27 \\
\hline Disney & $84,381,197$ & $4,438,193$ & 10 & 2.33 & 2.36 \\
\hline Best Film & $49,725,614$ & $2,669,100$ & 42 & 1.37 & 1.42 \\
\hline Gutek Film & $40,279,819$ & $1,650,253$ & 35 & 1.11 & 0.88 \\
\hline Interfilm & $35,789,677$ & $2,155,513$ & 3 & 0.99 & 1.15 \\
\hline SPI (SPInka) & $33,462,567$ & $2,054,858$ & 16 & 0.92 & 1.09 \\
\hline Vision & $30,188,936$ & $1,776,420$ & 15 & 0.83 & 0.95 \\
\hline Next Film & $25,697,936$ & $1,373,828$ & 4 & 0.71 & 0.73 \\
\hline CinePix & 0 & 0 & 0 & 0.00 & 0.00 \\
\hline
\end{tabular}


Yet, in 2014-2018 Kino Świat became the leader and dominated other market players (Table 3). The relative market share greater than one confirms this fact. Still, UIP holds second position in the ranking. Its income and audience reach approx. $98 \%$ and $93 \%$ of income and audience of the market leader. Market share of both distributors is over $43 \%$ both in terms of value and volume. At the same time, Warner and Monolith are other important distributors that are present on the Polish cinema market through all the period in question. Their strong position is, however, threatened by Disney that distributed its first productions on the Polish market as late as in 2012. Moreover, as shown in Tables 1-3, most of the films were broadcast in the discussed period by such distributors as UIP (over $20 \%$ of all films in the group), Monolith (over 15\%) and Kino Świat (over 14\%).

Table 3. Fifteen major cinema distributors in Poland by income (PLN) (2014-2018)

\begin{tabular}{|c|c|c|c|c|c|}
\hline Distributor & Income & Viewers & $\begin{array}{l}\text { No of } \\
\text { films }\end{array}$ & $\begin{array}{c}\text { Absolute } \\
\text { value share }\end{array}$ & $\begin{array}{c}\text { Absolute } \\
\text { volume } \\
\text { share }\end{array}$ \\
\hline Kino Świat & $935,115,419$ & $49,947,847$ & 162 & 21.98 & 22.28 \\
\hline UIP & $912,973,196$ & $46,690,866$ & 174 & 21.46 & 20.83 \\
\hline Disney & $568,046,472$ & $28,885,046$ & 48 & 13.35 & 12.88 \\
\hline Monolith & $464,882,933$ & 25994,995 & 141 & 10.93 & 11.59 \\
\hline Imperial CinePix & $414,580,242$ & $21,640,067$ & 76 & 9.74 & 9.65 \\
\hline Warner & $329,466,379$ & $16,827,816$ & 64 & 7.74 & 7.51 \\
\hline Forum Film & $227,265,841$ & $11,873,718$ & 45 & 5.34 & 5.30 \\
\hline Next Film & $183,340,098$ & $10,113,640$ & 27 & 4.31 & 4.51 \\
\hline ITI Cinema (Vue Movie) & $114,392,255$ & $6,333,771$ & 21 & 2.69 & 2.83 \\
\hline Interfilm & $49,669,080$ & $2,721,149$ & 3 & 1.17 & 1.21 \\
\hline Gutek Film & $37,155,821$ & $2,111,189$ & 28 & 0.87 & 0.94 \\
\hline Best Film & $17,889,386$ & $1,062,672$ & 21 & 0.42 & 0.47 \\
\hline SPI (SPInka) & 0 & 0 & 0 & 0.00 & 0.00 \\
\hline CinePix & 0 & 0 & 0 & 0.00 & 0.00 \\
\hline Vision & 0 & 0 & 0 & 0.00 & 0.00 \\
\hline
\end{tabular}

The analysis of a market share allows indicating the competitive position of a company relative to other companies operating on the market, showing what part of the market a company took over. The length of the period of distributor's presence on the market, as well as the number of the distributed titles, affect the high box office figures of all distributor's films. Thus, it seems that income per the number of distributed films is much more reliable indicator of distributor's investment decisions. In this case, the list of the fifteen major distributors on the market looks slightly different. Such distributors as Interfilm, Forum Film, ITI Cinema (Vue Movie) or Next Film play much more important role (Tables 4-6). 
Table 4. Fifteen major cinema distributors in Poland by income per film (PLN) (2002-2007)

\begin{tabular}{|l|r|r|}
\hline \multicolumn{1}{|c|}{ Distributor } & Income/film & \multicolumn{1}{c|}{ Viewers/film } \\
\hline Interfilm & $11,104,355$ & 851,316 \\
\hline Forum Film & $4,289,996$ & 294,466 \\
\hline ITI Cinema (Vue Movie) & $3,920,778$ & 274,020 \\
\hline Warner & $3,669,811$ & 250,127 \\
\hline UIP & $3,109,450$ & 199,912 \\
\hline CinePix & $2,935,846$ & 199,166 \\
\hline Monolith & $1,810,674$ & 125,274 \\
\hline Imperial CinePix & $1,586,536$ & 99,301 \\
\hline Vision & $1,513,187$ & 110,498 \\
\hline SPI (SPInka) & $1,330,878$ & 88,939 \\
\hline Kino Świat & $1,154,492$ & 75,843 \\
\hline Gutek Film & 824,233 & 50,919 \\
\hline Best Film & 778,658 & 51,823 \\
\hline Next Film & 0 & 0 \\
\hline Disney & 0 & 0 \\
\hline
\end{tabular}

Table 5. Fifteen major cinema distributors in Poland by income per film (PLN) (2008-2013)

\begin{tabular}{|l|r|r|}
\hline \multicolumn{1}{|c|}{ Distributor } & Income/film & \multicolumn{1}{c|}{ Viewers/film } \\
\hline Interfilm & $11,929,892$ & 718,504 \\
\hline Disney & $8,438,120$ & 443,819 \\
\hline Next Film & $6,424,484$ & 343,457 \\
\hline Forum Film & $6,037,872$ & 303,420 \\
\hline ITI Cinema (Vue Movie) & $5,165,146$ & 272,654 \\
\hline Warner & $4,993,263$ & 261,914 \\
\hline Imperial CinePix & $4,581,349$ & 222,929 \\
\hline UIP & $4,153,465$ & 211,339 \\
\hline Kino Świat & $3,492,066$ & 192,627 \\
\hline Monolith & $2,802,258$ & 144,762 \\
\hline SPI (SPInka) & $2,091,410$ & 128,429 \\
\hline Vision & $2,012,596$ & 118,428 \\
\hline Best Film & $1,183,943$ & 63,550 \\
\hline Gutek Film & $1,150,852$ & 47,150 \\
\hline CinePix & 0 & 0 \\
\hline
\end{tabular}

In the light of this research, Interfilm occupies the highest position in the rankings presented above as it has the biggest income per film and viewers per film. Since its operation on Polish market, Disney is just behind Interfilm. Interestingly, the income/film and the viewers/film of Next Film account for about $41 \%$ of the income/film and of the viewers/film of the market leader (Table 6). 
Table 6. Fifteen major cinema distributors in Poland by income per film (PLN) (2014-2018)

\begin{tabular}{|l|r|r|}
\hline \multicolumn{1}{|c|}{ Distributor } & Income/film & \multicolumn{1}{c|}{ Viewers/film } \\
\hline Interfilm & $16,556,360$ & 907,050 \\
\hline Disney & $11,834,302$ & 601,772 \\
\hline Next Film & $6,790,374$ & 374,579 \\
\hline Kino Świat & $5,772,317$ & 308,320 \\
\hline Imperial CinePix & $5,455,003$ & 284,738 \\
\hline ITI Cinema (Vue Movie) & $5,447,250$ & 301,608 \\
\hline UIP & $5,246,972$ & 268,338 \\
\hline Warner & $5,147,912$ & 262,935 \\
\hline Forum Film & $5,050,352$ & 263,860 \\
\hline Monolith & $3,297,042$ & 184,362 \\
\hline Gutek Film & $1,326,994$ & 75,400 \\
\hline Best Film & 851,876 & 50,603 \\
\hline SPI (SPInka) & 0 & 0 \\
\hline CinePix & 0 & 0 \\
\hline Vision & 0 & 0 \\
\hline
\end{tabular}

\subsection{Concentration and competitiveness of the market}

In the years 2002-2018, there was high market concentration in the Polish cinema distribution industry (Table 7). Between 2014 and 2018 approx. 68\% of the cinema distribution (in terms of value and volume) was realised by the four major distributors (Kino Świat, UIP, Disney, Monolith). Moreover, the value of the Herfindahl-Hirschman index for absolute value $(\mathrm{HHI}=1453)$ and volume market share $(\mathrm{HI}=1439)$ indicates a high level of competition (Table 8).

Table 7. C4 indexes for the cinema distribution market in Poland (2002-2018)

\begin{tabular}{|l|r|r|r|}
\hline \multicolumn{1}{|c|}{$\mathrm{C} 4$} & $2002-2007$ & $2008-2013$ & $2014-2018$ \\
\hline Income & 65.49 & 63.35 & 67.71 \\
\hline Viewers & 64.91 & 63.37 & 67.58 \\
\hline
\end{tabular}

Table 8. Herfindahl-Hirschman indexes for the cinema distribution market in Poland (2002-2018)

\begin{tabular}{|c|c|c|c|}
\hline Index & $2002-2007$ & $2008-2013$ & $2014-2018$ \\
\hline $\mathrm{HHI}$ & 1,377 & 1,365 & 1,453 \\
\hline HI & 1,344 & 1,352 & 1,439 \\
\hline
\end{tabular}




\section{Discussion}

Cinema distribution in Poland is a rapidly growing market. The market capacity survey showed that the number of auditorium is growing every year and the cinema becomes more accessible to the viewer. However, the Polish distribution sector is not homogeneous. Its first segment includes the so-called major distributors, that is the fifteen distribution companies who concentrate in their hands as much as $95 \%$ of market shares. Thanks to a small number of entities in the dominating group of the market it is possible to make agreements of both horizontal (between distributors) and vertical (with producers on the one hand, and cinemas or multiplexes on the other) nature. This leads to the strengthening of the negotiating position of the major distributors and further division of the market between main players. As a result, it may lead to an increase in the price of cinema tickets for films offered by these distributors and further strengthening of their market position. According to the research into the cinema audience (Cieślak \& Jaworowski, 2018), though viewers would like to pay less for cinema screenings, while willingness to pay more is declared only by the viewers of studio cinemas.

The analysis of the structure and the concentration of the sector in question shows that nowadays over half of the cinema distribution in Poland is concentrated in the hands of four companies (UIP, Kino Świat, Monolith and Disney), two of which (UIP, Disney) are foreign branches of the major American studios. What is more, the Polish office of Walt Disney Co. (Buena Vista) holds strong second position on the Polish film distribution market in terms of the income per film. This proves that the Polish cinema distribution market is under the influence of large international distribution companies. Therefore, it should not come as a surprise that Hollywood blockbusters are the main offer of the American majors in Poland. For example, the Polish branch of Walt Disney Co. distributes Walt Disney's films, while UIP screens films of such studios as Paramount Pictures, Universal Pictures and Metro-Goldwyn-Mayer/United Artists, without taking into account Polish productions. Another example of a company that distributes mainly American films is the Polish office of Warner Bros., which deals, among others, with the Warner Bros., New Line Cinema and Legendary Pictures projects. However, Imperial CinePix releases films of such studios as $20^{\text {th }} \mathrm{Centu-}$ ry Fox, Metro-Goldwyn-Mayer/United Artists, Paramount Pictures and DreamWorks. It does not distribute Polish films and rarely deals with European productions as these are of the interest of domestic companies, such as Kino Świat or Monolith. 
At the same time, it turns out that in order to reach a larger audience distributors in Poland join forces in the implementation of cost-intensive projects. It is usually a one-off cooperation that builds the competitive advantage of the market players and ends after the promotion of the film. It reduces the risk associated with the project, divides the distribution costs between cooperating entities, as well as allows them to combine the non-financial resources (experience, rights to a film) and budgets for marketing activities. Such cooperation is usually beneficial for the project and generates high income from tickets sold.

\section{Conclusions}

\subsection{Research contribution}

Thanks to the analysis, it was possible to distinguish a group of entities dominating the market and prove that the Polish cinema distribution market is strongly influenced by international (mainly American) distribution consortia. The results obtained in the research are similar with the existing literature findings, which concern other countries (e.g. Canada, New Zealand, Western Europe). This means that Poland is part of the trend of dominance of American distributors on domestic markets.

Moreover, it turns out that the film industry in Poland is developing dynamically and the market capacity, both in terms of value (income from cinema projections) and volume (number of viewers), increases every year. The proposed paper is, therefore, a contribution to a broader discussion on the cinema distribution in a country, where film distribution is still forming. The presented study is even more valuable when one realises that, surprisingly, the Polish cinema distribution market is not of particular interest to the majority of the researchers of the subject.

\subsection{Research implication}

There are implications of the paper findings for practitioners. The observation of the current trends and tastes of the audience, as well as an analysis of the market, an example of which is presented in the very paper, may be helpful in choosing a film venture that is attractive to invest in. This paper presents results of the research carried out with the use of simple statistical methods that may be used to examine the structure, the concentration and the competitiveness of the market of one's interest. 
All in all, the results of the conducted study shed new light on the poorly recognised cinema distribution market in Poland and provide an introduction to further research on the prospects of the mentioned sector in the near future.

\subsection{Research limitation and future works}

Limitations in the study relate primarily to the extent of research. Research results concern Poland and cannot be generalised to other countries. However, they complement research conducted in other countries confirming the thesis that the European distribution market is strongly dominated by the Hollywood majors.

In addition, studies refer only to the cinema distribution, not taking into account other channels of distribution as DVD, VOD and online distribution. It would also be worth exploring other distribution channels in the context of the concentration and structure of film distribution. The research conducted can be helpful in further research related to the film industry, too. In particular, the effects of concentration on the film distribution market require further analysis from the point of view of film studies, economics and cultural policy.

\section{References}

Act on cinematography of 30 June 2005, published in Dz.U. 2005, Nr 132 poz. 1111.

Adamczak, M. (2019, August). Hard power and film distribution: Transformation of distribution practices in Poland in the era of digital revolution. Studies in Eastern European Cinema. https://doi.org/10.1080/2040350X.2019.1648230

Adamczak, M., \& Klejsa, K. (2015). Badania dystrybucji filmowej: pola problemowe, stan wiedzy, perspektywy rozwoju [Film distribution research: Problems, state of knowledge, perspectives]. In: M. Adamczak \& K. Klejsa (Eds.), Wokót zagadnień dystrybucji filmowej [Around film distribution issues] (pp. 9-32). Łódź: Wydawnictwo PWSFTviT.

Branston, G., \& Stafford, R. (2010). The media student's book. London: Routledge.

Cieślak, Z., \& Jaworowski, M. (2018). Widz kinowy w Polsce. Raport z badania przeprowadzonego dla Filmweb Sp. z o.o. [Cinema viewer in Poland. Study report conducted for Filmweb Sp. z o.o.]. Warszawa: Polski Instytut Sztuki Filmowej.

Crane, D. (2014). Cultural globalization and the dominance of the American film industry: Cultural policies, national film industries, and transnational film. International Journal of Cultural Policy, 20(4), 365-382. https://doi.org/10.1080/10286632.2013. 832233

Dystrybutorzy. (2018). Retrieved from www.boxoffice.pl 
Jaciow, M., Galuszka, J., Wolny, R., Kucia, M., Kaczmarzyk, J., Dąbrowski, P., \& Kędzior, Z. (2011). Rynek audiowizualny w Polsce - diagnoza i perspektywy rozwoju (dla subrynku kinematografii) [The audio-visual market in Poland - diagnosis and development prospects (for the cinematography sub-market)]. Katowice: Fundacja Edukacja Bez Granic.

Kehoe, K., \& Mateer, J. (2015). The impact of digital technology on the distribution value chain model of independent feature films in the UK. The International Journal on Media Management, 17, 93-108. https://doi.org/10.1080/14241277.2015. 1055533

Lobato, R. (2007). Subcinema. Theorizing marginal film distribution. Limina, 13, 113-120.

Majewska, B. (2017). Analiza interesariuszy polskiego rynku filmowego [Analysis of stakeholders of the Polish film market]. Zeszyty Naukowe Politechniki Częstochowskiej. Zarzadzanie, 25(1), 140-155. https://doi.org/10.17512/znpcz.2017.1.1.13

Magder, T. (1996). Film and video production. In M. Dorland (Ed.), The cultural industries of Canada: Problems, policies and prospects (pp. 145-177). Toronto: James Lorimer \& Company.

Mruk, H. (Ed.). (2003). Analiza rynku [Market analysis]. Warszawa: Polskie Wydawnictwo Ekonomiczne.

Muñoz Larroa, A., \& Ferrer-Roca, N. (2017). Film distribution in New Zealand: Industrial organisation, power relations and market failure. Media Industries, 4,(2). https:// doi.org/10.3998/mij.15031809.0004.201

Pardo, A., \& Sánchez-Tabernero, A. (2012). Effects of market concentration in theatrical distribution: The case of the Big Five Western European countries. International Journal on Media Management, 14(1), 51-71. https://doi.org/10.1080/14241277. 2011.597365

Scott, A. J. (2002). A new map of Hollywood: The production and distribution of American motion pictures. Regional Studies, 36(9), 957-975. https://doi.org/10.1080/ 0034340022000022215

Scott, A. J. (2004). Hollywood and the world: The geography of motion-picture distribution and marketing. Review of International Political Economy, 11(1), 33-61. https://doi.org/10.1080/0969229042000179758

Statistics Poland. (2019a). Bank Danych Lokalnych [Local Data Bank]. Retrieved from https://bdl.stat.gov.pl/BDL/start

Statistics Poland. (2019b). Culture in 2018. Retrieved from https://stat.gov.pl/en/ topics/culture-tourism-sport/culture/culture-in-2018,1,11.html

Tepperman, C. (2017). Bureaucrats and movie czars: Canada's feature film policy since 2000. Media Industries, 4, 62-80. https://doi.org/10.3998/mij.15031809.0004.204

UK Film Council. (2000). Towards a sustainable UK film industry. London: Author.

De Vany, A. (2004). Hollywood economics. How extreme uncertainty shapes the film industry. London: Routledge. 
Walls, W. D., \& McKenzie, J. (2012). The changing role of Hollywood in the global movie market. Journal of Media Economics, 25(4), 198-219. https://doi.org/ 10.1080/08997764.2012.729544

Zajiček, E. (1983). Film polski. Ekonomika i organizacja produkcji [The Polish film. Economics and organisation of the production]. Warszawa: Polskie Wydawnictwo Naukowe.

Zajiček, E. (1992). Poza ekranem. Kinematografia polska 1918-1991 [Beyond the screen. Polish cinematography in 1918-1991]. Warszawa: Filmoteka Narodowa, Wydawnictwa Artystyczne i Filmowe.

Zajiček, E. (2009). Poza ekranem. Kinematografia polska 1896-2005 [Beyond the screen. Polish cinematography in 1896-2005]. Warszawa: Stowarzyszenie Filmowców Polskich and Studio Filmowe Montevideo. 